\title{
Study on Lipid Fractions of Streptococcus thermophilus by TLC, GC and GC/MS Techniques
}

\author{
V. Pelizzola ${ }^{a}$, M. Povolo ${ }^{*}$, , A. Avalli ${ }^{\mathrm{a}}$, B. Bottari ${ }^{\mathrm{b}}$, E. Neviani ${ }^{\mathrm{b}}$ and G. Contarini ${ }^{\mathrm{a}}$ \\ ${ }^{a}$ CRA-Istituto Sperimentale Lattiero-Caseario, Lodi, Italy \\ ${ }^{b}$ Università di Parma-Dipartimento Genetica, Biologia dei Microrganismi, Antropologia, Evoluzione, Parma, Italy
}

\begin{abstract}
In this research the lipid fraction of two strains of Streptococcus thermophilus was studied. Lipids were extracted by applying Folch method and fractioned by thin layer chromatography (TLC). Fatty acid composition was determined both before TLC, on the total fat extracted, and after TLC on diacylglycerol and apolar fractions. Gas chromatographic analysis was performed by using both flame ionization (FID) and mass spectrometer (MS) detector. The main difference between the two strains was the presence of short and medium chain fatty acids in food-born S. thermophilus. Moreover one of the most important bacterial fatty acids, C19 cyclopropane, was detected only in diacylglycerols, which, as reported in literature, are formed transiently as intermediates in the biosynthesis of glycerophospholipids.
\end{abstract}

Keywords: Bacterial lipids, FAME, TLC, GC, MS.

\section{INTRODUCTION}

The composition of bacteria lipids, which account for roughly $50 \%$ of cytoplasmatic membrane, has been studied due to its potential use for classification purpose [1-6]. The fatty acid composition of the whole lipid fraction, particularly in Gram-negative bacteria, has been widely investigated to support microbial characterization and to provide targets for antibacterial drugs. It is known that microbial fatty acid composition is dependent upon several factors and it is often modified in response to environmental physicochemical parameters such as oxygen, temperature, nutrients, growth phase and $\mathrm{pH}$ value [7-16]. Different analytical procedures have been applied for the determination of bacterial fatty acids: acid or alkaline direct transesterification of the cells [17], methylation of the whole fat extracted, preceded or not by saponification $[4,5,8,12,16]$. Gas chromatography (GC), gas chromatography/mass spectrometry (GC/MS) and pyrolysis/mass spectrometry were further applied to identify and quantify the different fatty acids as methylesters (FAME). Bacterial lipids contain appreciable amounts of myristic (C14), stearic (C18) and C16-C18 monoenoic fatty acids. The most abundant monoenoic acid is cis-vaccenic acid (18:1-c11). In addition, fatty acids with branched-chain and cyclopropane ring are synthesised by bacteria and produce an increase in the membrane fluidity. This effect is comparable to that provided by the double bonds of polyunsaturated fatty acids in higher organisms [18]. There are few references available on the composition of the different bacterial lipid fractions, and all are devoted to the evaluation of the most polar lipid fraction mainly including polyesters of fatty acids and molecules with a polar head-group (e.g., phospholipids, glycolipids, phosphoglycolipids) $[3,19,20]$. Thin-layer chromatography (TLC), together with a high polar mobile phase, was usually applied to obtain the separation of the polar fraction from the whole lipid matrix, and, at the same

*Address correspondence to this author at the CRA-Istituto Sperimentale Lattiero-Caseario, Lodi, Italy; Tel: +390371 45011; Fax: +39 0371 35579; E-mail:mpovolo@ilclodi.it time, to separate the different classes of compounds on the basis of the different polar head-groups [21-24]. By using TLC a fraction which migrated at the solvent front was found and it was defined as "neutral lipids". Being polar lipids, not only the most represented but also the most interesting fraction, due to their importance in the membrane structure and behaviour, limited the attention given to the study of the neutral fraction. The present investigation was designed to evaluate the composition of lipids of Streptococcus thermophilus with particular attention to the study of the less polar fractions. Few data are available on the lipid composition of this bacterial species, even though it is one of the most important constituents of the microbial starters used in dairy industry, particularly in the production of yogurt and several Italian cheeses, such as Mozzarella, Pecorino and Gorgonzola [25]. TLC, GC and GC/MS, with different capillary columns, were applied.

\section{MATERIALS AND METHODOLOGY}

\section{Materials}

Two Streptococcus thermophilus strains, wild type ATCC19258 (WT) and isolated from yogurt (ST6), were obtained from the collection of the Institute of Dairy Science of Lodi. M17 broth (BIOLIFE, Milan, Italy) was used as growing medium: $42 \mathrm{~g}$ of M17 were suspended in 1 litre of distilled water, transferred into $6 \mathrm{ml}$ test tubes and sterilised at $121^{\circ} \mathrm{C}$ for 15 minutes. Bacteria were revitalised by growing them in $6 \mathrm{ml}$ of broth at $42^{\circ} \mathrm{C}$. This procedure was repeated twice. Then $1 \% \mathrm{v} / \mathrm{v}$ of these cultures was inoculated in increasing volumes of growing medium, from $30 \mathrm{ml}$ to 21 , in order to obtain a sufficient amount of cells (about $20 \mathrm{~g}$ ) for the fat extraction. The cells were harvested when the culture was at the stationary phase, since literature data reported that, in this period, the fatty acid composition is quite stable [2]. Cells were harvested from the medium broth and then washed twice with sterile water, by centrifugation at $8000 \mathrm{~g}$ $\mathrm{x} 10$ min with ALC PK121 centrifuge (ALC International, Cologno Monzese, Milan, Italy). 
For the recognition of methyl esters, the Reference Material CRM164 (Sigma-Aldrich, Milan, Italy) [26], consisting of milk fat natural triglycerides, and the standard mixture of bacterial acid methyl esters BAME Mix (Sigma-Aldrich, Milan, Italy) were analysed by both GC/FID and GC/MS.

\section{Lipid Extraction}

Lipids were extracted by homogenisation of the harvested cells with chloroform-methanol $(2: 1, \mathrm{v} / \mathrm{v})$ in a blender at $25^{\circ} \mathrm{C}$, according to Folch et al. [27]. The extract was shaken and equilibrated with one-fourth its volume of a saline solution $(0.1 \mathrm{M}$ of $\mathrm{KCl})$. The solvent phase was filtered and evaporated under vacuum. This procedure was performed on two portions of cells, to obtain two lipid extracts from each culture.

\section{Thin Layer Chromatography}

Low polar and neutral lipids were separated by preparative TLC on silica gel precoated plates (Merck, Darmstadt, Germany), using n-hexane/diethyl ether/formic acid (50:50:0.5) as mobile phase. Suitable pure standards (triolein, dinonadecanoin, monononadecanoin, tridecanoic acid and cholesterol. Sigma-Aldrich, Milan, Italy) were loaded in the right side of the plate for the recognition of the fractions. The plate was sprayed with a solution of Rhodamine $G$ in ethanol $(0.15 \% \mathrm{w} / \mathrm{v})$. Each band was detected by examining the dried plate under UV light at $254 \mathrm{~nm}$. Bands were scraped off and lipids were recovered by extracting three times with $5 \mathrm{ml}$ of chloroform and $5 \mathrm{ml}$ of diethyl ether alternatively.

The fractions recovered were analysed before and after transmethylation adopting the operative conditions described-below.

\section{Transmethylation}

Total fat extracted and the fractions recovered after TLC were diluted in hexane and derivatised as methylesters by addition of $\mathrm{KOH} 2 \mathrm{~N}$ in methanol [28]. Alkaline conditions were adopted, since Lambert and Moss [29] observed that acid transmethylation destroys cyclopropane fatty acids.

One microlitre of the upper phase containing the fatty acid methyl esters (FAME), was injected twice into GC. The same procedure was applied to CRM164 to obtain the standard FAME mixture.

\section{GAS CHROMATOGRAPHY AND GAS CHROMA- TOGRAPHY/MASS SPECTROMETRY}

The analysis of underivatised TLC lipid fractions was performed on a TraceGC coupled with a TraceMS Plus mass spectrometer (Thermo Electron Corporation, Woburn, MA). PTV injector in splitless mode was used with the following conditions: $80^{\circ} \mathrm{C}$ for $0.1 \mathrm{~min}$, up to $350^{\circ} \mathrm{C}$ at the rate of $10^{\circ} \mathrm{C} / \mathrm{s}$ and $1 \mu \mathrm{l}$ of the sample was injected manually. A CBTAP (Varian, Palo Alto, CA) capillary column ( $25 \mathrm{~m} \mathrm{x} 0.25$ $\mathrm{mm}$ I.D., $0.10 \mathrm{~mm}$ film thickness) was used. Oven temperature was held at $120^{\circ} \mathrm{C}$ for $3 \mathrm{~min}$, programmed to $200^{\circ} \mathrm{C}$ at a rate of $8^{\circ} \mathrm{C} / \mathrm{min}$, held at $200^{\circ} \mathrm{C}$ for $10 \mathrm{~min}$ and programmed to $340^{\circ} \mathrm{C}$ at a rate of $3^{\circ} \mathrm{C} / \mathrm{min}$. Helium was used as carrier gas at a flow rate of $1.0 \mathrm{ml} / \mathrm{min}$. Interface was held at $360^{\circ} \mathrm{C}$ and MS source at $250^{\circ} \mathrm{C}$. Acquisition was performed in EI mode $(70 \mathrm{eV})$ by 0.4 scans/s and the mass range used was $\mathrm{m} / \mathrm{z}, 70-900$.

GC analysis of FAMEs with flame ionization detector (FID) was performed by HP6890 (Agilent Technologies, Palo Alto, CA) and DB23 low bleed (J\&W, Agilent Technologies, Palo Alto, CA) capillary column $(30 \mathrm{~m} \times 0.32 \mathrm{~mm}$ I.D., $0.25 \mu \mathrm{m}$ film thickness). On-column injection $(1 \mu \mathrm{l})$ was adopted and hydrogen $(1 \mathrm{ml} / \mathrm{min})$ was used as carrier gas. Temperature program was as follows: $40^{\circ} \mathrm{C}$ for $3 \mathrm{~min}$, $25^{\circ} \mathrm{C} / \mathrm{min}$ up to $120^{\circ} \mathrm{C}$ for $1 \mathrm{~min}, 4^{\circ} \mathrm{C} / \mathrm{min}$ up to $162^{\circ} \mathrm{C}$ for 2 $\min , 8^{\circ} \mathrm{C} / \mathrm{min}$ up to $220^{\circ} \mathrm{C}$ for $3 \mathrm{~min}$; detector was held at $250^{\circ} \mathrm{C}$.

FAME analysis by GC/MS was carried out with HP 5890 series II coupled with mass spectrometer HP 5989A (Agilent Technologies, Palo Alto, CA). Interface, source and quadrupole temperatures were $220^{\circ} \mathrm{C}, 200^{\circ} \mathrm{C}$ and $100^{\circ} \mathrm{C}$, respectively. In order to obtain a better separation a longer capillary column was adopted. A CP-WAX 52CB (Varian, Palo Alto, CA) capillary column $(60 \mathrm{~m} \times 0.32 \mathrm{~mm}$ I.D., $0.5 \mu \mathrm{m}$ film thickness) was used and $1 \mu \mathrm{L}$ of the sample was injected. Splitless injection at $250^{\circ} \mathrm{C}$ was used. Oven temperature was $180^{\circ} \mathrm{C}$ for $45 \mathrm{~min}, 1^{\circ} \mathrm{C} / \mathrm{min}$ up to $220^{\circ} \mathrm{C}$. Acquisition was made in EI mode $(70 \mathrm{eV})$ by $1.6 \mathrm{scans} / \mathrm{s}$; the mass range used was $\mathrm{m} / \mathrm{z} 35-350$. The identification of fatty acids was performed by comparison with both the mass spectra of the Wiley library [30] and those of the CRM164 fat reference and BAME mixture analysed under the same conditions.

\section{RESULTS AND DISCUSSION}

Fig. (1) shows, for the total lipids extracted from the two $S$. thermophilus strains, the GC profiles of FAMEs, whose composition (area \%) is reported in Table $\mathbf{1}$.

In both WT and ST6 strains the straight-chain saturated acids $\mathrm{C} 14: 0$ and $\mathrm{C} 16: 0$, the monounsaturated acids C16:1 and $\mathrm{C} 18: 1$ and the cyclopropane acid C19cyc are the most abundant ones. Moreover C18:1 peak seemed to include at least two main isomers. The most evident difference in ST6 lipids was the presence of about $4 \%$ of short and medium straight-chain fatty acids (C4 to $\mathrm{C} 12$ ), characteristic of milk fat. This result could be explained by the incorporation of exogenous fatty acids, deriving from the original matrix (i.e., milk) where the bacteria grew before their isolation. To our knowledge the presence of the short chain fatty acids has hardly ever been observed by other authors on lipids extracted from lactic acid bacteria [17]. This lack of information could be due to either the adoption of GC operative conditions not being suitable for the separation of these low boiling point compounds, or the evaluation of non-dairy foodborne strains $[5,9,11,12,16,31]$. Nevertheless, the possible incorporation of exogenous fatty acids has already been reported by Goldfine [32] and Asselineau and Asselineau [33].

In order to investigate the composition of the fat extracted, a TLC separation was performed and the mobilities of lipids were compared to those of triacylglycerol (TG), diacylglycerol (DG), monoacylglycerol, cholesterol and free fatty acid standards (Fig. 2). The TLC conditions applied to the total fat extracted were designed to provide the separation between neutral and low polar compounds. The same conditions are usually applied in the evaluation of the most abundant classes of lipids of higher organisms [34,35]. As a 

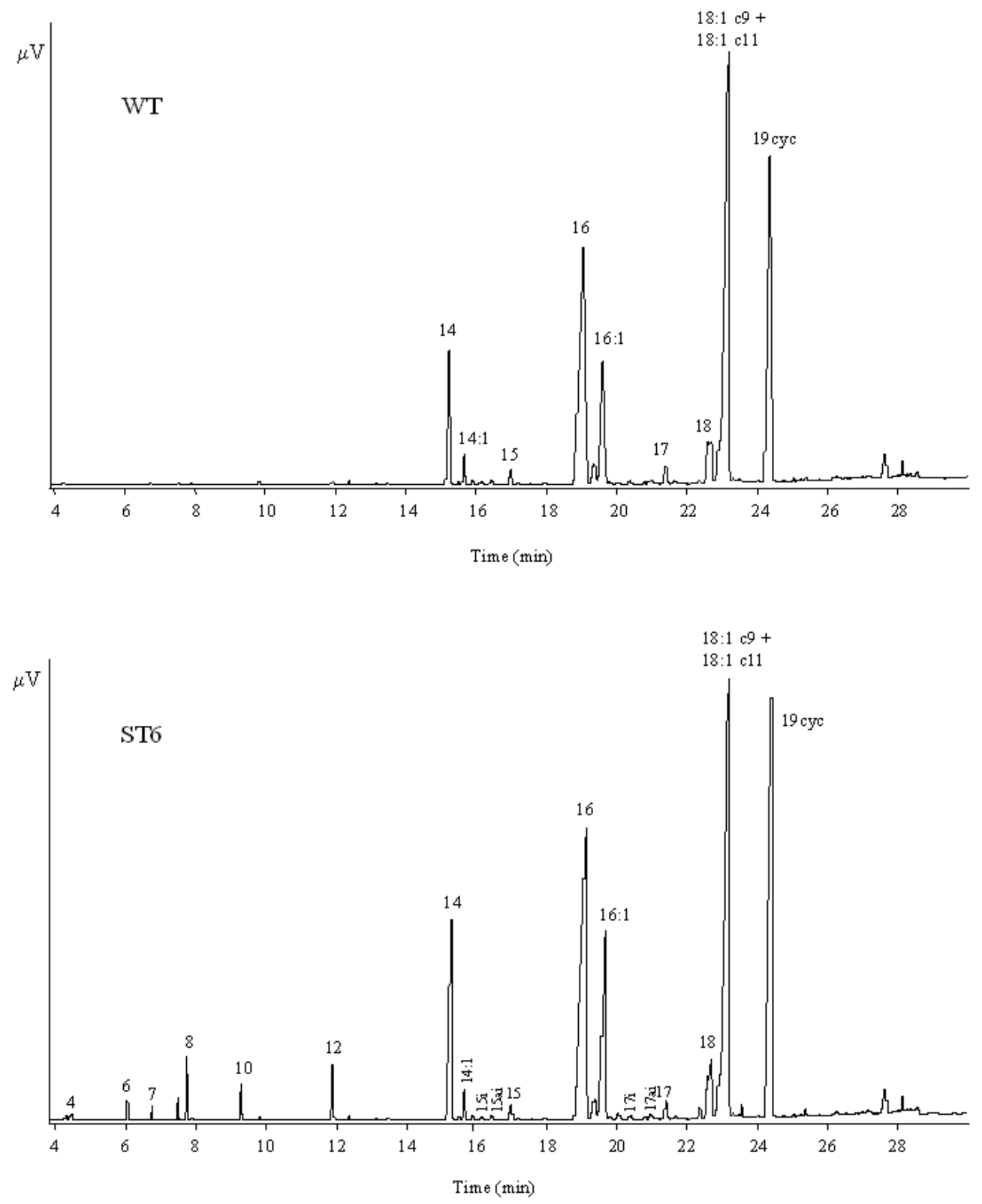

Fig. (1). WT and ST6 strain: GC/FID profiles of FAMEs obtained from total lipids.

consequence the high polar fraction, including glucosyl diglycerides and phospholipids, did not migrate on the silica plate. The main bands observed were those corresponding to DG and TG standards. A slight band was detected in correspondence of free fatty acid standard, while no evidence of the presence of monoacylglycerols was observed. The band corresponding to the cholesterol was not clearly separated from that of DGs and consequently the two regions were recovered in only one fraction.

DG and TG bands of WT sample were analysed by GC/MS equipped with a CB-TAP polar capillary column withstanding high temperatures (Fig. 3).

The TG fraction showed, in the first part of the profile, the presence of straight chain hydrocarbons from 22 to 33 carbon atoms. The MS identification of the major peaks with a retention time higher than 61 minutes demonstrated the presence of triacylglycerols having 38 to 48 carbon atoms and including $\mathrm{C} 10$ to $\mathrm{C} 18$ fatty acids. The compounds eluting with a retention time ranging from 50 to 61 minutes, produced mass spectra with fragments demonstrating the presence of fatty acids from 14 to 18 carbon atoms, but neither the molecular weight, nor the retention time corresponded to TG molecules including those types of fatty acids. Thus it was considered that these molecules were esters of fatty acids having a backbone different from glycerol. Occurrence of triacylglycerols in bacteria has only rarely been described, while the other fatty acid esters detected in bacteria [36,37] did not match the chemical behaviour and the mass spectra of our samples. The comparison with the spectra of authentic standards of cholesteryl myristate, cholesteryl palmitate and cholesteryl stearate, analysed under the same conditions, allowed this hypothesis to be excluded as well. Further investigations are in progress in order to perform the complete recognition of all the compounds eluting in this fraction. The MS identification of the diacylglycerol 
fraction confirmed the presence of these structures having 30 to 36 carbon atoms and including not only $\mathrm{C} 14$ to $\mathrm{C} 18$ fatty acids but also C19cyc. The peak eluting at 40.7 minutes was identified as cholesterol. The presence of cholesterol in the membrane of lactic acid bacteria was in accordance with other authors that demonstrated the assimilation of this molecule from the growth media [38,39].

Table 1. Fatty Acid Composition (Area \%) of Total Lipids of the Two Strains of St. thermophilus

\begin{tabular}{|c|c|c|c|c|}
\hline & \multicolumn{2}{|c|}{ WT } & \multicolumn{2}{|c|}{ ST6 } \\
\hline & Mean & SD & Mean & SD \\
\hline $\mathrm{C} 4$ & & & 0.1 & 0.01 \\
\hline C6 & & & 0.2 & 0.04 \\
\hline $\mathrm{C} 7$ & & & 0.2 & 0.08 \\
\hline $\mathrm{C} 8$ & & & 0.3 & 0.01 \\
\hline $\mathrm{C} 10$ & & & 1.4 & 0.14 \\
\hline C10:1 & & & 0.1 & 0.01 \\
\hline $\mathrm{C} 12$ & & & 1.4 & 0.11 \\
\hline $\mathrm{C} 14$ & 6.3 & 0.35 & 7.9 & 0.28 \\
\hline C14:1 & 0.1 & 0.04 & 0.8 & 0.07 \\
\hline C15 i & & & 0.2 & 0.02 \\
\hline C15 a-iso & & & 0.2 & 0.06 \\
\hline $\mathrm{C} 15$ & 0.5 & 0.21 & 0.7 & 0.10 \\
\hline $\mathrm{C} 16$ & 21.8 & 0.99 & 24.8 & 0.42 \\
\hline C16:1 & 12.9 & 1.34 & 10.2 & 0.99 \\
\hline $\mathrm{C} 17 \mathrm{i}$ & & & 0.3 & 0.01 \\
\hline C17 a-iso & & & 0.1 & 0.01 \\
\hline $\mathrm{C} 17$ & 0.5 & 0.14 & 0.6 & 0.11 \\
\hline $\mathrm{C} 17: 1$ & & & 0.1 & 0.04 \\
\hline $\mathrm{C} 18 \mathrm{i}$ & & & 0.3 & 0.06 \\
\hline $\mathrm{C} 18$ & 0.7 & 0.21 & 3.3 & 0.51 \\
\hline $\mathrm{C} 18: 1 \sum^{\mathrm{a}}$ & 34.9 & 0.85 & 26.3 & 0.57 \\
\hline С19cyc & 22.3 & 0.57 & 20.6 & 1.20 \\
\hline
\end{tabular}

Both TG and DG fractions were transesterified and analysed for their fatty acid composition.

Fig. (4) shows the GC profiles of FAMEs obtained from ST6 strain, while Table 2 reports the percentage composition for both the strains.

It is worth noting that two peaks were again present in the region of C18:1. Due to the minor concentration with respect to the FAMEs obtained from the total lipids, the two peaks appeared better resolved. The samples were analysed also by GC/MS and the comparison with the retention data of the natural standard (CRM 164) and BAME standard analysed with both $30 \mathrm{~m}$ (GC/FID) and $60 \mathrm{~m}$ (GC/MS) columns, led to the conclusion that the two C18:1 peaks were c9 and c11 octadecenoic acid positional isomers. This conclusion was in accordance with the results reported by Rozes et al. [31] and Dionisi et al. [17] on lactic acid bacteria FAME composition and was consistent with the separation performances of the capillary column adopted [40].

Short and medium chain fatty acids were detected in both apolar and diacylglycerol fractions of ST6. Regarding the distribution of the other fatty acids, some similarities between the two strains were observed: C14, C16, C18 and C18:1c9 were higher in apolar fraction, while C16:1 and C18:1c11 were more abundant in diacylglycerol fraction. Moreover, fatty acid C19cyc was detected only in the diacylglycerol fraction and it showed the same distribution as C18:1c11. The presence of C19cyc only in DG fraction confirmed that these compounds are intermediates of the biosynthesis of phospholipids and glucosyl diglycerides as observed by White and Frerman [41] and Hildebrand and Law [42] who found C19cyc in the fraction of polar-complex lipids.

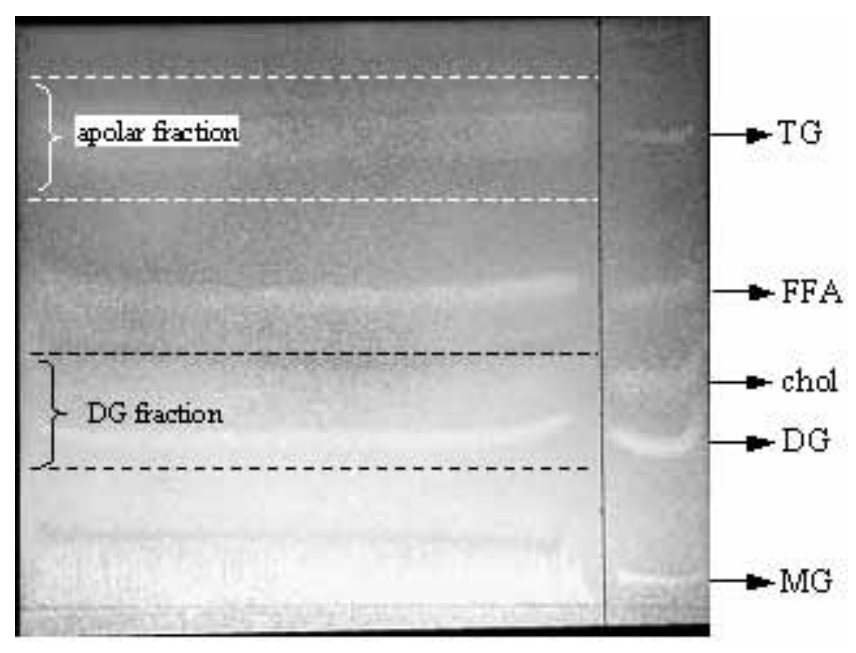

Fig. (2). TLC plate.

\section{CONCLUSIONS}

The composition of the usually named "neutral" fraction of bacterial lipids, i.e. the remaining one after the separation of polar and complex lipids, showed the presence of different compounds belonging to the chemical classes of free fatty acids, diglycerides, triglycerides, sterols, hydrocarbons and other neutral esters of fatty acids. As far as the foodborne strains are concerned, this work showed the presence of a matrix effect on the fatty acid composition. Moreover the presence of C19cyc in DG fraction put forward the hypothesis that the process of cyclopropane ring formation from C18:1 occurred directly in the free diacylglycerol form, before the polar head-group had been bonded. This result suggests that the detailed study of the constituents of each lipid fraction, together with the fatty acid analysis of the whole fat matrix, could provide useful information about the biochemical pathways responsible for the biosynthesis of bacterial lipids. 

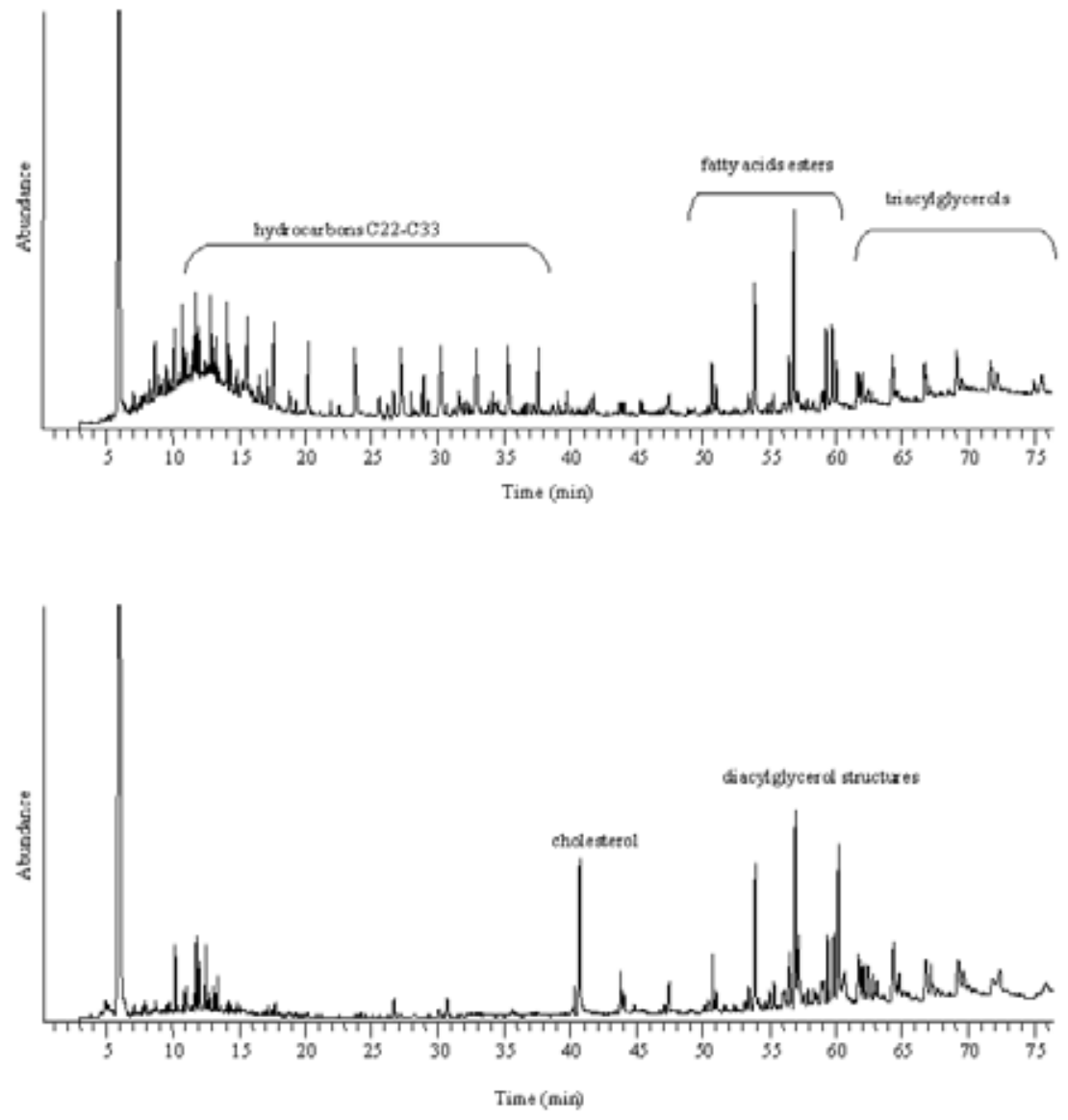

Fig. (3). WT strain: GC/MS profiles of the underivatized apolar and diacylglycerol fractions.
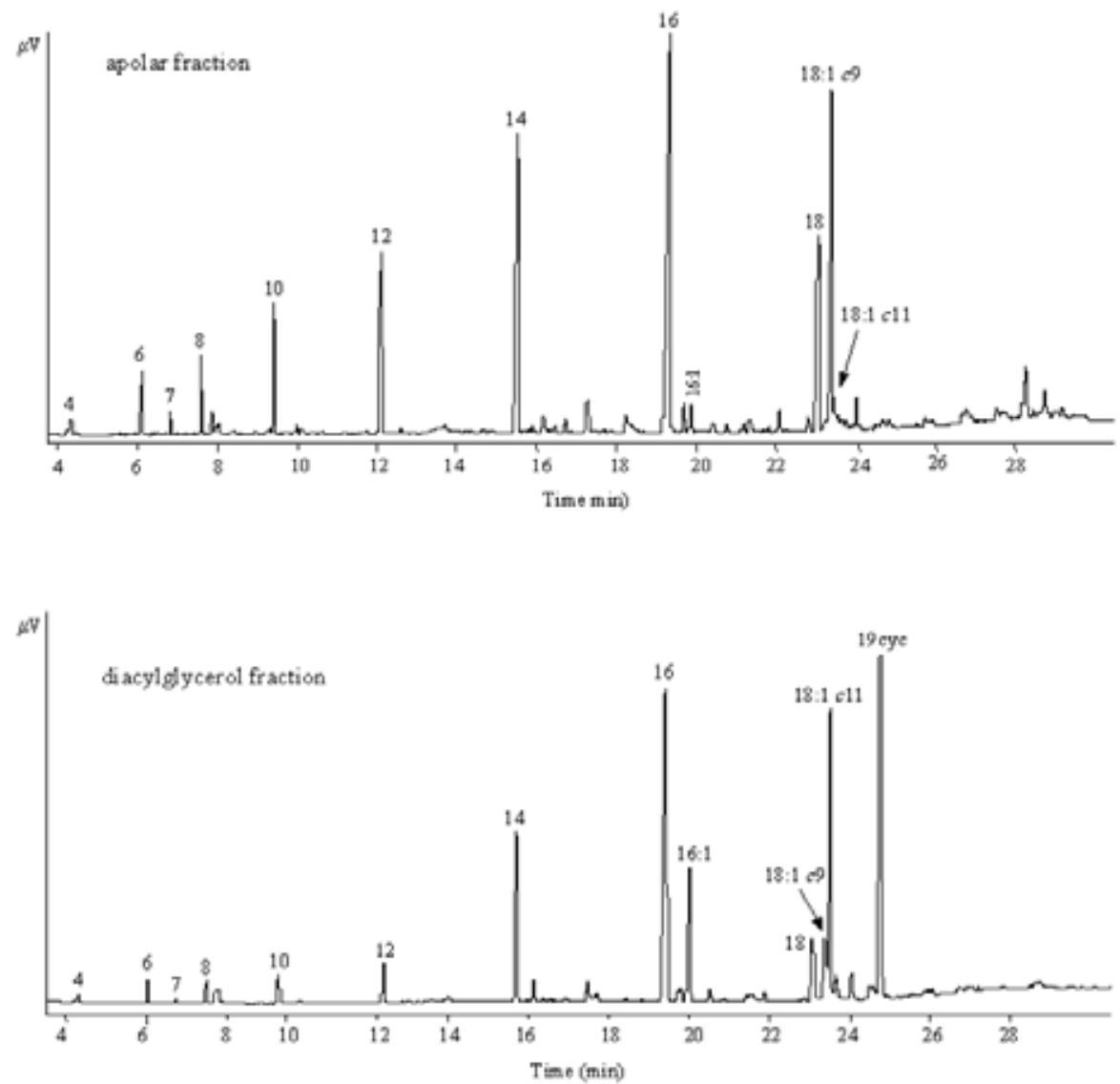

Fig. (4). ST6 strain: GC/FID profiles of FAMEs obtained from the apolar and diacylglycerol fractions. 
Table 2. WT and ST6 Strains: Fatty Acid Composition (Area $\%)$ of Apolar and Diacylglycerol Fractions

\begin{tabular}{|c|c|c|c|c|c|c|c|c|}
\hline & \multicolumn{4}{|c|}{ WT } & \multicolumn{4}{|c|}{ ST6 } \\
\hline & \multicolumn{2}{|c|}{ Apolar } & \multicolumn{2}{|c|}{ DG } & \multicolumn{2}{|c|}{ Apolar } & \multicolumn{2}{|c|}{ DG } \\
\hline & Mean & SD & Mean & SD & Mean & SD & Mean & SD \\
\hline $\mathrm{C} 4$ & & & & & 0.4 & 0.17 & 0.3 & 0.04 \\
\hline C6 & & & & & 1.1 & 0.14 & 0.4 & 0.04 \\
\hline C7 & & & & & 0.4 & 0.01 & 0.1 & 0.04 \\
\hline $\mathrm{C} 8$ & & & & & 1.5 & 0.18 & 0.6 & 0.07 \\
\hline $\mathrm{C} 10$ & & & & & 3.8 & 0.07 & 1.4 & 0.28 \\
\hline $\mathrm{C} 10: 1$ & & & & & 0.3 & 0.03 & 0.1 & 0.01 \\
\hline $\mathrm{C} 12$ & & & & & 7.1 & 0.21 & 2.0 & 0.71 \\
\hline $\mathrm{C} 14$ & 11.5 & 0.49 & 8.7 & 0.57 & 14.1 & 0.89 & 10.7 & 0.64 \\
\hline C14:1 & & & & & 0.8 & 0.04 & 1.0 & 0.18 \\
\hline $\mathrm{C} 15 \mathrm{i}$ & & & & & 0.4 & 0.01 & & \\
\hline C15 a-iso & & & & & 0.7 & 0.03 & & \\
\hline $\mathrm{C} 15$ & 1.4 & 0.14 & 1.2 & 0.28 & 1.7 & 0.02 & 1.2 & 0.07 \\
\hline C16 & 42.6 & 1.77 & 34.6 & 1.13 & 34.9 & 1.12 & 27.4 & 1.06 \\
\hline C16:1 & & & 1.7 & 0.07 & 1.3 & 0.08 & 9.1 & 0.57 \\
\hline $\mathrm{C} 17 \mathrm{i}$ & & & & & 0.6 & 0.09 & & \\
\hline C17 a-iso & & & & & 0.6 & 0.07 & & \\
\hline $\mathrm{C} 17$ & & & 0.6 & 0.14 & 0.6 & 0.18 & 0.9 & 0.11 \\
\hline C17:1 & & & & & 1.0 & 0.11 & & \\
\hline $\mathrm{C} 18 \mathrm{i}$ & & & & & 0.5 & 0.1 & & \\
\hline $\mathrm{C} 18$ & 27.2 & 1.48 & 17.6 & 1.06 & 11.3 & 1.24 & 4.7 & 1.06 \\
\hline $\mathrm{C} 18: 1 c 9$ & 16.3 & 0.64 & 4.0 & 0.57 & 15.1 & 1.04 & 4.0 & 1.41 \\
\hline $\mathrm{C} 18: 1 c 11$ & 0.9 & 0.21 & 20.6 & 0.71 & 1.1 & 0.11 & 15.0 & 0.66 \\
\hline C19cyc & & & 11.0 & 0.42 & & & 19.8 & 1.34 \\
\hline
\end{tabular}

\section{REFERENCES}

[1] Basile, F.; Voorhees, K.J.; Hadfield, T. Appl. Environ. Microb., 1995, 61(4), 1534-9.

[2] Decallone, J.; Delmee, M.; Wauthoz, P.; El Lioui, M.; Lambert, R. J. Food Protect. 1991, 54(3), 217-24.

[3] Ivanova, E.P.; Zhukova, N.V.; Svetashev, V.I.; Gorshkova, N.M.; Kurilenko, V.V.; Frolova, G.M.; Mikhailov, V.V. Curr. Microbiol., 2000, $41,341-5$.

[4] Rizzo, A.F.; Korkeala, H.; Mononen, I. Appl. Environ. Microbiol., 1987, 53(12), 2883-8.

[5] Schmitt, P.; Mathot, A.G.; Divies, C. Milchwissenscaft, 1989, 44(9), 556-9.

[6] Wauthoz, P.; El Lioui, M.; Decallonne, J. J. Food Prot., 1995, 58(11), 1234-40.
[39] Dambekodi, P.C.; Gilliland, S.E. J. Dairy Sci., 1998, 81, 1818-24.

[40] Kramer, J.K.G.; Blackadar, C.B.; Zhou, J. Lipids, 2002, 37(8), 82335 .

[41] White, D.C.; Frerman, F.E. J. Bacteriol., 1968, 95(6), 2198-2209.

[42] Hildebrand, J.G.; Law, J.H. Biochemistry, 1964, 3, 1304-8.

Bishop, E.; Bermingham, M.A.C. Antimicrob. Agents Chemother., 1973, 4(3), 378-9.

Drici-Cachon, Z.; Cavin, J.-F.; Diviès, C. Lett. Appl. Microbiol., 1996, 22, 331-4.

Furga, M.L.; Cabrera, G.M ; Font de Valdez, G.; Disalvo, A.; Seldes, A.M. J. Appl. Microbiol., 2000, 88, 342-8.

. 24, 109-12.

(1977, 33(3), 489-96. 2000, 67, 241-7. 55, 47-51.

Johnsson, T.; Nikkila, P.; Toivonen, L.; Rosenqvist, H.; Laasko, S. Appl. Environ. Microbiol., 1995, 61(12), 4497-9.

Muñoz-Rojas, J.; Bernal, P.; Duque, E.; Godoy, P.; Segura, A.; Ramos, J.-L. Appl. Environ. Microbiol., 2006, 72(1), 472-7.

Oshima, M.; Miyagawa, A. Lipids, 1974, 9(7), 476-80. 1107-15.

Christie, W.W. In Lipid Analysis; Christie, Ed.; The Oily Press: Bridgwater, UK, 2003; pp.3-36.

Bacteriol., 1995, 177(21), 6304-8.

Shimada, H.; Nemoto, N.; Shida, Y.; Oshima, T.; Yamagishi, A. J. Bacteriol., 2002, 184(2), 556-63.

Bateman, H.G.; Jenkins, T.C. J. Agric. Food Chem., 1997, 45, 1324.

Mastronicolis, S.; German, J.B.; Smith, G.M. Food Chem., 1996, 3), 451-6.

.3.

White, D.C.; Frerman, F.E. J. Bacteriol., 1967, 94(6), 1854-67.

(atti, G.; Neviani, E. In Microbiologia e tecnologia lattierocasearia. Qualità e sicurezza; Tecniche Nuove: Milano, IT, 2006; pp. 145-67.

Commission of the European Communities CRM 1641993 Report 15277.

(1957, 726, 497-509.

International Standard 15884. International Organization for Standardization:Geneva, Swiss, 2002.

(18) 7. Wiley-Interscience: New York, 1988. Appl. Microbiol., 1993, 17 126-31.

Goldfine, H. J. Lipid Res., 1984, 25, 1501-7.

Asselineau, C.; Asselineau, J. Biochem. Cell Biol. 1990, 68, 37986

Bridgwater, UK, 2003; pp.105-35.

Mariani, C.; Contarini, G.; Zucchetti, S.; Toppino, P.M. J. High Resol. Chrom., 1990, 13, 356-60. 367-76.

Pinkart, H.C.; Devereux, R.; Chapman, P.J. J. Microbiol. Methods, 1988, 34, 9-15.

Noh, D.O.; Kim, S.H.; Gilliland S.E. J. Dairy Sci., 1997, 80, 310713. 